\title{
The CYP19A1 (TTTA)n repeat polymorphism, but not Arg264Cys polymorphism, may affect the risk of prostate cancer: evidence from a meta-analysis
}

\author{
Lei Guo \\ The Affiliated Hospital of Qingdao University \\ Yanan Liu \\ The Affiliated Hospital of Qingdao University

\section{Lijun Liu} \\ The Affiliated Hospital of Qingdao University

\section{Shixiu Shao} \\ The Affiliated Hospital of Qingdao University

\section{Yanwei Cao} \\ The Affiliated Hospital of Qingdao University

\section{Jiaming Guo} \\ The Affiliated Hospital of Qingdao University \\ Niu Haitao ( $\nabla$ niuht0532@126.com ) \\ The Affiliated Hospital of Qingdao University
}

\section{Research}

Keywords: CYP19A1, Arg264Cys, (TTTA)n repeat, polymorphism, prostate cancer, meta-analysis

Posted Date: January 22nd, 2021

DOI: https://doi.org/10.21203/rs.3.rs-56054/v3

License: (c) (i) This work is licensed under a Creative Commons Attribution 4.0 International License. Read Full License 


\section{Abstract}

Background: Abnormal aromatase (CYP19A1) expression may participate in prostate cancer (PCa) carcinogenesis. However, results of studies on the CYP19A1 gene polymorphisms and PCa are conflicting.This meta-analysis aimed to systematically evaluate the association between the CYP19A1 Arg264Cys polymorphism and (TTTA)n repeat polymorphism and PCa.

Methods: Electronic databases (PubMed, EmBase, ScienceDirect, and Cochrane Library) were comprehensively searched to identify eligible studies. The strength of association between the Arg264Cys polymorphism and PCa was assessed by pooled odds ratio (OR) and $95 \%$ confidence interval $(95 \% \mathrm{Cl}$ ) in allelic, dominant, recessive, homozygous, and heterozygous genetic models. To analyze the impact of the (TTTA)n repeat polymorphism, we took sequentially the N-repeat allele (where $\mathrm{N}$ equals $7,8,10,11,12$, and 13) as the minor allele and the sum of all the other alleles as the major allele. The ORs and $95 \% \mathrm{Cls}$ were calculated in the allelic model; this analysis was performed individually for each repeat number.

Results: Pooled estimates of nine studies addressing the Arg264Cys polymorphism indicated that this polymorphism was not associated with PCa risk in the overall population and in the Caucasian and Asian subgroups. The 8-repeat allele in the (TTTA)n repeat polymorphism increased $\mathrm{PCa}$ risk in the overall population ( $\mathrm{OR}=1.34,95 \% \mathrm{Cl}=1.14-1.58, P=0.001)$ and in the subgroup with population-based (PB) controls ( $\mathrm{OR}=1.41,95 \% \mathrm{Cl}=1.13-1.74, P=0.002)$ as well as in the subgroup of studies using capillary electrophoresis to identify this polymorphism $(\mathrm{OR}=1.34,95 \% \mathrm{Cl}=1.09-1.65, \mathrm{P}=0.006)$.

Conclusions: The meta-analysis indicated that the CYP19A1 (TTTA)n repeat polymorphism, but not Arg264Cys polymorphism may affect PCa risk.

\section{Background}

Prostate cancer ( $\mathrm{PCa})$, the most common non-cutaneous cancer in males, is the second leading cause of cancer death in the USA and represents a major public health challenge [1]. The carcinogenesis of PCa is multifactorial, and its details remain obscure. Besides the age, race, obesity, geography, smoking, certain lifestyle factors, radiation, and urinary tract infections, genetic susceptibility is also considered a candidate risk factor for $\mathrm{PCa}$ [2]. Men whose first-degree relatives suffered from PCa have a higher risk of this malignancy than those without affected first-degree relatives (relative risk (RR) $=2.48$ ), and the risk is even higher when these men are younger than 65 [3]. Moreover, the prevalence and prognosis of PCa vary among racial groups, and the incidence and mortality are highest in men of African descent [4]. These findings highlight the possible function of genetic factors in the onset of PCa. Multiple genes, including the RANSEL, MSR1, HOXB13, CHD5, EPHB2, PIWI2 genes, etc.,have been reported to be associated with the susceptibility to PCa [5, 6]. Thus, insights into genetic risk factors underlying PCa may help to identify the high-risk population.

$\mathrm{PCa}$ is androgen-dependent, and estrogens provide protection against PCa because of their anti-androgenic effects. In contrast to females, in which estrogens are secreted by a central organ (ovaries), the main source of estrogens in males is the peripheral conversion of androgen precursors [7]. The enzyme aromatase (CYP19A1), mainly expressed in the gonads and peripheral tissues, including the prostate, is essential for the conversion of androgens to estrogens and represents an important therapeutic target in breast cancer [7, 8]. Aberrant aromatase expression was detected in PCa tissue, but not in benign prostate hyperplasia (BPH) tissue, and may contribute to the recurrence of $\mathrm{PCa}$ [9-11]. Liang and coworkers documented that CYP19A1 expression was significantly higher in castration-resistant prostate cancer (CRPC) than in primary PCa, and patients with the elevated expression of CYP19A1 had shorter overall survival after first hormone therapy than patients with lower expression [12]. The level of CYP19A1 expression was also correlated with the Gleason score in primary PCa patients [12]. Together, these findings suggest that CYP19A1 might contribute to the onset, development, and prognosis of PCa, and its response to treatment. CYP19A1 is encoded by the CYP19A1 gene mapped to chromosome 15q21.2 [13]. Although the polymorphism of the CYP19A1 gene is related to the levels of sex hormones, including testosterone, in men with and without PCa, the impact of polymorphism of this gene on PCa remains controversial $[14,15]$. 
Several studies have focused on the associations between the Arg264Cys polymorphism in exon 7 and the tetranucleotide simple tandem (TTTA)n repeat polymorphism in intron 4 of CYP19A1 gene and PCa, but the results were not unequivocal [16-19]. To address this issue, we have performed the meta-analysis of data from all eligible case-control studies focused on the relation between these two forms of polymorphisms and $\mathrm{PCa}$.

\section{Methods}

\section{Literature search}

The electronic databases of PubMed, EmBase, ScienceDirect, and Cochrane Librarywere searched comprehensively and systematically by two independent investigators from inception to July 17, 2019 to identify relevant studies. The key words applied were "CYP19A1", “aromatase”, "rs700519”, "Arg264Cys”, "R264C", “TTTA" and "polymorphism” in combination with "prostate cancer" or "prostatic neoplasms". The lists of references in the retrieved publications were also manually screened for potentially eligible studies.

\section{Inclusion and exclusion criteria}

The inclusion criteria were: (1) case-control, cross-sectional, or nested case-control studies on the CYP19A1 Arg264Cys polymorphism and/or (TTTA)n repeat polymorphism in PCa; (2) studies published in English; (3) studies with adequate allele and genotype data for both the cases and the controls to calculate the odds ratios (ORs) and $95 \%$ confidence intervals (Cls). In the case of the overlap of subjects in different studies, only the most complete study was involved.

The exclusion criteria were: (1) reviews, meta-analyses, or case reports; (2) case-only or family-based studies; (3) studies with intervention strategies which might modify the risk of PCa; (4) studies not providing allele/genotype frequencies or adequate data allowing their calculation; (5) studies on the polymorphisms of other genes or other prostate diseases; (6) duplicate publications; (7) publications written in languages other than English.

\section{Data extraction and quality assessment}

Two investigators independently extracted the following data from selected studies: the first author's name, publication year, study design, ethnicity and country of the study population, source of controls, sample size, age of cases and controls, sample acquisition and genotyping method, allele and genotype distributions in each polymorphism (stated in the publication or calculated from the study data using standard formulae). Disagreements were resolved by discussing and consulting the third investigator. The Newcastle-Ottawa Scale (NOS) was used to assess the quality of case-control and nested case-control studies [20] and studies scored 6 or more stars were considered as having a high quality[21].

\section{Statistical analysis}

The meta-analysis was conducted with the STATA software 12.0 (STATA Corp., College Station, TX, USA).In each study, the Hardy-Weinberg equilibrium (HWE) in the control group was tested by the Pearson chi-square test. To evaluate the strength of association between the Arg264Cys polymorphism and PCa, pooled ORs with corresponding 95\% Cls were calculated in 5 genetic models: allelic (T vs. C), dominant (CT + TT vs. CC), recessive (TT vs. CT + CC), homozygous (TT vs. CC) and heterozygous (CT vs. CC) models. For the (TTTA)n repeat polymorphism, the $\mathrm{N}$ repeat allele (with $\mathrm{N}$ equal to 7,8,10,11,12, and 13 , sequentially) was considered as the minor allele, and all the other alleles were added together as the major allele. The ORs and $95 \% \mathrm{Cls}$ were calculated in the allelic model. The significance of ORs was determined by the Z-test, and $P<0.05$ was considered statistically significant. Heterogeneity among studies was assessed by $P$ statistics. . When $P$ was less than $50 \%$, the fixed-effect model (Mantel-Haenszel method) was applied. Otherwise, the random-effects model (DerSimonian and Laird method) was used. Additionally, subgroup analyses based on ethnicity and source of controls were performed. Sensitivity analysis was conducted to assess the stability of the pooled results; individual studies were omitted one at a time, and the pooled results were recalculated. Begg's funnel plots and Egger's linear regression test were conducted to 
detect potential publication bias [22]; an asymmetric funnel plot suggests a possible publication bias and $\mathrm{P}<0.05$ in Egger's test indicates statistically significant publication bias [23].

\section{Results}

\section{Selection and characteristics of eligible studies}

According to the inclusion and exclusion criteria, a total of 14 studies [14, 16-19, 24-32] were deemed eligible for this metaanalysis (Figure 1 detailed the study selection process). Among them, 8 studies investigated only the Arg264Cys polymorphism [14, 16-18, 24-26, 28], 5 studies explored only the (TTTA)n repeat polymorphism[19, 29-32], and 1 study focused on both polymorphisms[27]. The main characteristics of these studies are listed in Supplementary Table 1 (see Additional file 1) and Supplementary Table 2 (see Additional file 2). With the exception of the work of Fukastu et al (2004) with a score of 5 , all studies were considered of high quality base on the NOS $\geq 6$. Association between the CYP19A1 Arg264Cys polymorphism and PCa risk

Nine studies (7 case-control studies and 2 nested case-control studies), which recruited a total of 11,824 patients and 11,368 control subjects, addressed the relationship between the Arg264Cys polymorphism and PCa (see Supplementary Table 1)[14, 16-18, 24-28]. These studies enrolled Caucasians (4 studies), Asians (2 studies), Indians (1 study), AfricanAmericans (1 study), and subjects of mixed ethnicities (1 study). One study employed intervention measures (finasteride) that might confer PCa risk and might conceal the real situation of this polymorphism in PCa; therefore, only data in the placebo arm in this study were considered [28]. In 2 studies, genotype distributions in the control groups deviated from HWE $[14,18]$. Controls were hospital-based (HB) in 3 studies, population-based (PB) in 5 studies, and both HB and PB in 1 study. One study merely recruited cases with a family history of PCa in a first-degree relative [17], 1 study described the ratio of familial cases in all participants [25], while the remaining 7 studies did not provide information about family history. Peripheral blood were used to detect this polymorphism in 7 studies[14, 16, 17, 25-28], while peripheral blood or frozen prostate tissues were used in the other 2 studies[18, 24].

The allele and genotype frequencies in the overall population and all subgroups were summarized in Table 1.The overall pooled results and subgroup analyses are listed in Table 2. Neither the T allele nor the TT genotype was associated with $\mathrm{PCa}$ in the overall population, Caucasians, or Asians (Figure 2 displayed non-significant association between the $\mathrm{T}$ allele and overall PCa risk). Subgroup analyses could not be performed for African-Americans, Indians, or mixed ethnicities since each of these ethnicities was included only in one study. Subgroup analysis stratified by the source of controls was also conducted. When PB controls were considered, no evident association was found between the Arg264Cys polymorphism and PCa in any genetic model. Nevertheless, an association between the Arg264Cys polymorphism and PCa was observed under the dominant model (CT+TT vs. $\mathrm{CC}$ : $\mathrm{OR}=1.35,95 \% \mathrm{Cl}=1.02-1.78, P=0.04)$ and heterozygous model (CT vs. TT: $\mathrm{OR}=1.40,95 \% \mathrm{Cl}=1.04-1.88, P=0.03)$ in the $\mathrm{HB}$ subgroup. Subgroup analysis could not be accomplished for the $\mathrm{PB}+\mathrm{HB}$ subgroup since only one study included PB+HB controls. We further conducted subgroup analyses based on the sample acquisition and genotyping method, respectively. No significant association was detected in these subgroups (Table 2).

\section{Association between the CYP19A1 (TTTA)n repeat polymorphism and PCa risk}

Six studies ( 5 case-control studies and 1 nested case-control study) which recruited a total of 1488 cases and 1621 controls were analyzed (see Supplementary Table 2)[19, 27, 29-32]. Peripheral blood were used in all these studies to detect the (TTTA)n repeat polymorphism. Three of them were conducted in Asians, 1 each in Caucasians,Indians and subjects of

mixed ethnicities. The repeat numbers ranged from 7 to 14, but the 9-repeat allele was not detected in 4 studies [29-32] , and the 14-repeat allele was identified only in 1 study [27]. Thus, the 7-, 8-, and 10-13-repeat alleles were considered in this metaanalysis. Soni and coworkers [19] did not find 10,11, and 13 repeats either in patients or in controls, so that their study could not be included in the analysis of these three alleles. For the same reason, the study of Tang [32] was not used in the analysis of the 13-repeat allele. 
The pooled results are listed in Table 3. Only the 8-repeat allele was significantly associated with the risk of PCa in the overall population $(\mathrm{OR}=1.34,95 \% \mathrm{Cl}=1.14-1.58, P=0.001)$ (Figure 3$)$, while all the other alleles appeared not related to the overall PCa risk. Among the 6 studies addressing the 8-repeat allele, 1 was performed in Caucasians, 3 in Asians, 1 in Indians, and 1 in subjects of mixed ethnicities. Therefore, subgroup analysis only applied to Asians and yielded a nonsignificant result $(\mathrm{OR}=1.27,95 \% \mathrm{Cl}=0.88-1.85, P=0.17)$. . In the subgroup analysis based on the source of controls, the 8repeat allele was a risk factor of $\mathrm{PCa}$ in the $\mathrm{PB}$ subgroup $(\mathrm{OR}=1.41,95 \% \mathrm{Cl}=1.13-1.74, P=0.002)$. Although in the subgroup analysis stratified by the genotyping method, the 8-repeat allele increased PCa susceptibility in the subgroup of studies using capillary electrophoresis to investigate the (TTTA)n repeat polymorphism $(O R=1.34,95 \%=1.09-1.65, P=0.006)$, the results should be treated cautiously because there were only 2 studies using this genotyping method.

\section{Heterogeneity and Sensitivity Analysis}

Although there was considerable heterogeneity among the studies in certain subgroups in this meta-analysis (Table 2 and Table 3), sensitivity analysis showed that the synthetic results were not materially altered by omitting any single study, indicating the stability of the results (Figure 4 and Figure 5).

\section{Publication bias}

Begg's funnel plots did not reveal any evidence of obvious asymmetry in studies on the Arg264Cys polymorphism (Figure 6), and Egger's test with $P>0.05$ further verified the absence of publication bias (Table 2). For the (TTTA)n repeat polymorphism, Begg's funnel plots and Egger's test indicated the absence of publication bias except for the 7-, 8- and 13repeat alleles $(P<0.05$; Table 3$)$.

\section{Discussion}

The human CYP19A1gene, a member of the cytochrome P450 superfamily of genes, spans approximately 123 base pairs (bp) and comprises 9 translated exons (exons II-X) and 1 untranslated exon I spliced at the 5' end as well as 9 introns [33, 34]. Several distinct polymorphisms in the CYP19A1 gene have been studied in PCa, among which the Arg264Cys polymorphism and (TTTA)n repeat polymorphism are the most extensively investigated. However, studies on these two polymorphisms in PCa did not provide consistent results, possibly due to the low statistical power of every single study or limited impact of these polymorphisms on PCa. A meta-analysis, a powerful statistical tool, may clarify the conflicting results of previous research and provide a more precise estimation of the impact of Arg264Cys and (TTTA)n repeat polymorphisms on $\mathrm{PCa}[35]$.

The $\mathrm{C} \rightarrow \mathrm{T}$ transition (rs700519) in exon 7 of the CYP19A1 gene leads to a single amino acid substitution, of Arg by Cys, at codon 264, and the T allele has been reported to enhance aromatase enzymatic activity, affecting the conversion of androgens. This modification may alter the risk of several disorders, such as breast cancer, polycystic ovary syndrome (PCOS), and endometrial cancer [36-39]. The current meta-analysis failed to detect any association between the Arg264Cys polymorphism and the overall PCa risk. Given the well-established ethnic disparity in PCa incidence, subgroup analysis based on ethnicity was conducted. No relationship was identified between the Arg264Cys polymorphism and PCa in Caucasians or Asians. Studies were also divided according to the differences between the enrolled control subjects, the sample acquisition and the genotyping method, and the CT+TT and CT genotypes were found to be associated with PCa susceptibility in the subgroup of HB controls. However, these results should be interpreted with caution, since the relatively low number of studies and small sample sizes in each subgroupprevent statistical interpretation with confidence and do not exclude the possibility that these correlations might be incidental. In addition, evident heterogeneity among the analyzed studies have also weakened the reliability of the results.

The (TTTA)n repeat polymorphism is located at the intron 4 of the CYP19A1gene, and its effect on the enzymatic activity of aromatase has not been unequivocally established $[11,40]$. However, this polymorphism may affect mRNA stability or be in 
linkage disequilibrium with other polymorphisms, including a nearby 3 bp TCT deletion in conjunction with the 7-repeat only, and a T/C change in the 3 '-untranslated region in which the TT genotype is linked to 8 and longer repeats [11, 41]. The repeat numbers reported in the literature range from 7 to 15 , with two major peaks at 7 and 11 or 12 repeats [40, 42, 43]. Luigi and colleagues discovered that a high (TTTA)n repeat genotype (10 or more repeats) might be associated with a higher serum level of estradiol $\left(E_{2}\right)$ in a group of Italian men older than 55 [44]. Previous studies have demonstrated that the (TTTA)n repeat polymorphism might convert susceptibility to several diseases, including PCOS, gynecomastia, and breast cancer [43, 45-47]. In studies related to PCa, Sonoda found that 11 or more repeats were associated with an increased risk of PCa [31], while Huang and coworkers identified a similar relationship for homozygous 7-repeats [30]. Conversely, Soni reported no association between (TTTA)n polymorphism and PCa [19]. These inconsistent findings might be attributed to discrepancies in ethnicity, country of origin, sample size, phenotypes, type of controls, and genotyping methods. The current meta-analysis uncovered a significant association between the 8-repeat allele and the overall risk of PCa, which was largely driven by studies utilizing PB controls and capillary electrophoresis to detect this polymorphism. On the other hand, the 7-,10-13-repeat alleles seemed to have nothing to do with PCa risk. English language criterion in literature search, exclusion of studies without adequate amount of data, and the preferential publication of studies that achieved statistical significance might lead to the publication bias detected by Egger's test in studies on the 8-repeat allele, which is not unusual in meta-analyses [48]. However, the low heterogeneity and statistically robust findings in sensitivity analysis suggest that the obtained results are relatively reliable.

To the best of our knowledge, this is the first meta-analysis investigating the association between the Arg264Cys and (TTTA)n repeat polymorphism of the CYP19A1 gene in PCa. However, several limitations should be taken into consideration. First, the number of eligible studies is limited and the sample sizes are restricted. Moreover, the number of controls didn't match the number of cases in 2 studies $[16,25]$. These may affect the statistical power of the determination of the significance of associations. Second, due to the lack of access to the original data of analyzed studies, it was impossible to adjust for other PCa risk factors such as age, family history, obesity, lifestyle factors, and gene-gene or geneenvironment interactions. Third, the inclusion of research published in English with enough data for calculation might have introduced publication bias. Fourth, the non-uniform selection of cases and controls across different studies may also bias the results. A similar effect might have been produced by the deviation from HWE noted in certain studies, possibly due to bias in the selection of control subjects or genotyping errors. And fifth, studies about the Arg264Cys polymorphism were mostly conducted in the Caucasian population. While, studies about the (TTTA)n repeat polymorphism were mostly conducted in the Asian population. Therefore, these studies were not adequate to identify the genetic etiology of PCa, the prevalence of prognosis of which vary among racial groups. Therefore, well-designed studies with larger sample sizes are warranted to verify the conclusion of the present study.

\section{Conclusions}

In summary, this meta-analysis provided evidence of the association between the 8-repeat allele in the CYP19A1 (TTTA)n repeat polymorphism and susceptibility to $\mathrm{PCa}$ in the overall population. Conversely, the Arg264Cys polymorphism in the CYP19A1 gene appeared to have no impact on the overall risk of PCa. Further studies are necessary to fully understand the role of these two polymorphisms in PCa, and to facilitate early identification of subjects at high risk of PCa.

\section{Abbreviations}

PCa: prostate cancer; RR: relative risk; BPH: benign prostate hyperplasia; CRPC: castration-resistant prostate cancer; OR: odds ratio; Cl: confidence interval; NOS: Newcastle-Ottawa Scale; HWE: Hardy-Weinberg equilibrium; HB: hospital-based; PB: population-based; bp: base pairs; PCOS: polycystic ovary syndrome.

\section{Declarations}




\section{Ethics approval and consent to participate}

All the data supporting our findings in this paper were freely downloaded from the PubMed, EmBase, ScienceDirect, and Cochrane Library. No ethical approval or written informed consent for participation was required.

\section{Consent for publication}

Not applicable.

\section{Availability of data and materials}

All data for this study are publicly available and are ready for the public todownload at no cost from the official websites of the PubMed, EmBase, ScienceDirect, and Cochrane Library. There is no need to have the formal permission to use data for this study. The sources and data robustness have been described in the "Methods" section.

\section{Competing interests}

The authors declare that they have no competing interests.

\section{Funding}

This research did not receive any specific grant from funding agencies in the public, commercial, or not-for-profit sectors.

\section{Authors' contributions}

LG and YL carried out the data search, selection, and study quality assessment. LL and SS performed the statistical analysis. LG, YL, YC and JG drafted the manuscript. HN conceived the study and participated in critical revision of the manuscript. All authors have read and approved the final version of the manuscript and agreed with the order of presentation of the authors.

\section{Acknowledgements}

Not applicable.

\section{References}

1. Siegel RL, Miller KD, Jemal A. Cancer statistics, 2018. CA: A Cancer Journal for Clinicians 2018; 68:7-30.

2. Cuzick J, Thorat MA, Andriole GL, Brawley OW, Brown PH, Culig Z, Eeles RA, Ford LG, Hamdy FC, Holmberg L. Prevention and early detection of prostate cancer. Lancet Oncology 2014; 15:484-492.

3. Kicinski M, Vangronsveld J, Nawrot TS. An epidemiological reappraisal of the familial aggregation of prostate cancer: a meta-analysis. PLOS ONE 2011; 6.

4. Shenoy D, Packianathan S, Chen AM, Vijayakumar S. Do African-American men need separate prostate cancer screening guidelines? BMC Urology 2016; 16:19-19.

5. Tosun H, Demirtaş A, Sönmez G, Tombul Ş, Akalın H, Özkul Y. Can the expression level of PIWIL 2 gene be a serum marker for prostate cancer? A single-center prospective study. Turkish journal of urology 2019; 45:S22-S25.

6. Boyd LK, Mao X, Lu YJ. The complexity of prostate cancer: genomic alterations and heterogeneity. Nature reviews Urology 2012; 9:652-664.

7. Rahman H, Hofland J, Foster PA. In touch with your feminine side: how oestrogen metabolism impacts prostate cancer. Endocrine-related Cancer 2016; 23.

8. Regan MM, Neven P, Giobbiehurder A, Goldhirsch A, Ejlertsen B, Mauriac L, Forbes JF, Smith IE, Lang I, Wardley AM. Assessment of letrozole and tamoxifen alone and in sequence for postmenopausal women with steroid hormone 
receptor-positive breast cancer: the BIG 1-98 randomised clinical trial at 8.1 years median follow-up. Lancet Oncology 2011; 12:1101-1108.

9. Ellem SJ, Schmitt JF, Pedersen J, Frydenberg M, Risbridger GP. Local aromatase expression in human prostate is altered in malignancy. The Journal of Clinical Endocrinology and Metabolism 2004; 89:2434-2441.

10. Gianfrilli D, Pierotti S, Pofi R, Leonardo C, Ciccariello M, Barbagallo F. Sex steroid metabolism in benign and malignant intact prostate biopsies: Individual profiling of prostate intracrinology. BioMed Research International 2014; 2014:464869-464869.

11. Celhay O, Yacoub M, Irani J, Dore B, Cussenot O, Fromont G. Expression of estrogen related proteins in hormone refractory prostate cancer: association with tumor progression. The Journal of Urology 2010; 184:2172-2178.

12. Liang Z, Cao J, Tian L, Shen Y, Yang X, Lin Q, Zhang R, Liu H, Du X, Shi J. Aromatase-induced endogenous estrogen promotes tumour metastasis through estrogen receptor-a/matrix metalloproteinase 12 axis activation in castrationresistant prostate cancer. Cancer Letters 2019.

13. Sebastian S, Bulun SE. A Highly Complex Organization of the Regulatory Region of the Human CYP19 (Aromatase) Gene Revealed by the Human Genome Project. The Journal of Clinical Endocrinology and Metabolism 2001; 86:46004602.

14. Travis RC, Schumacher FR, Hirschhorn JN, Kraft P, Allen NE, Albanes D, Berglund G, Berndt SI, Boeing H, Buenodemesquita HB. CYP19A1 Genetic Variation in Relation to Prostate Cancer Risk and Circulating Sex Hormone Concentrations in Men from the Breast and Prostate Cancer Cohort Consortium. Cancer Epidemiology, Biomarkers \& Prevention 2009; 18:2734-2744.

15. Kanda S, Tsuchiya N, Narita S, Inoue T, Huang M, Chiba S, Akihama S, Saito M, Numakura K, Tsuruta H. Effects of functional genetic polymorphisms in the CYP19A1 gene on prostate cancer risk and survival. International Journal of Cancer 2015; 136:74-82.

16. Modugno F, Weissfeld JL, Trump DL, Zmuda JM, Shea PR, Cauley JA, Ferrell RE. Allelic Variants of Aromatase and the Androgen and Estrogen Receptors: Toward a Multigenic Model of Prostate Cancer Risk. Clinical Cancer Research 2001; 7:3092-3096.

17. Suzuki K, Nakazato H, Matsui H, Koike H, Okugi H, Kashiwagi B, Nishii M, Ohtake N, Nakata S, Ito K. Genetic polymorphisms of estrogen receptor alpha, CYP19, catechol-O-methyltransferase are associated with familial prostate carcinoma risk in a Japanese population. Cancer 2003; 98:1411-1416.

18. Onsory K, Sobti RC, Albadran Al, Watanabe M, Shiraishi T, Krishan A, Mohan H, Kaur P. Hormone receptor-related gene polymorphisms and prostate cancer risk in North Indian population. Molecular and Cellular Biochemistry 2008; 314:2535 .

19. Soni A, Bansal A, Mishra AK, Batra J, Singh LC, Chakraborty A, Yadav DS, Mohanty NK, Saxena S. Association of androgen receptor, prostate-specific antigen, and CYP19 gene polymorphisms with prostate carcinoma and benign prostatic hyperplasia in a north Indian population. Genetic Testing and Molecular Biomarkers 2012; 16:835-840.

20. Stang A. Critical evaluation of the Newcastle-Ottawa scale for the assessment of the quality of nonrandomized studies in meta-analyses. European Journal of Epidemiology 2010; 25:603-605.

21. Piovezan JM, Premaor MO, Comim FV. Negative impact of polycystic ovary syndrome on bone health: a systematic review and meta-analysis. Human reproduction update 2019; 25:633-645.

22. Langhorne $P$, . Bias in meta-analysis detected by a simple, graphical test. Prospectively identified trials could be used for comparison with meta-analyses. Bmj 1998; 316:471.

23. Egger M, Smith GD, Schneider M, Minder CE. Bias in meta-analysis detected by a simple, graphical test. BMJ 1997; 315:629-634.

24. Fukatsu T, Hirokawa Y, Araki T, Hioki T, Murata T, Suzuki H, Ichikawa T, Tsukino H, Qiu D, Katoh T. Genetic polymorphisms of hormone-related genes and prostate cancer risk in the Japanese population. Anticancer Research 
$2004 ; 24: 2431-2437$.

25. Sarma A, Dunn R, La, Ray A, Wang Y, Lange E, Cooney K. Genetic polymorphisms in CYP17, CYP3A4, CYP19A1, SRD5A2, IGF-1, and IGFBP-3 and prostate cancer risk in African-American men: the Flint Men's Health Study. Prostate 2010; 68:296-305.

26. Holt SK, Kwon EM, Fu R, Kolb S, Feng Z, Ostrander EA, Stanford JL. Association of variants in estrogen-related pathway genes with prostate cancer risk. The Prostate 2013; 73:1-10.

27. Kachakova D, Mitkova A, Popov E, Beltcheva O, Vlahova A, Dikov T, Christova S, Mitev V, Slavov C, Kaneva R. Polymorphisms in androgen metabolism genes AR, CYP1B1, CYP19, and SRD5A2and prostate cancer risk and aggressiveness in Bulgarian patients. Turkish Journal of Medical Sciences 2016; 46:626-640.

28. Price DK, Chau CH, Till C, Goodman PJ, Leach RJ, Johnsonpais TL, Hsing AW, Hoque A, Parnes HL, Schenk JM. Association of androgen metabolism gene polymorphisms with prostate cancer risk and androgen concentrations: Results from the Prostate Cancer Prevention Trial. Cancer 2016; 122:2332-2340.

29. Suzuki K, Nakazato H, Matsui H, Koike H, Okugi H, Ohtake N, Takei T, Nakata S, Hasumi M, Yamanaka H. Association of the genetic polymorphism of the CYP19 intron 4 [TTTA]n repeat with familial prostate cancer risk in a Japanese population. Anticancer Research 2003; 23:4941-4946.

30. Huang Y, Chen M, Lin M, Chung M, Chang Y, Huang WJS, Wu TT, Hsu J, Yang S, Chen YMA. CYP19 TCT tri-nucleotide Del/Del genotype is a susceptibility marker for prostate cancer in a Taiwanese population. Urology 2007; 69:996-1000.

31. Sonoda T, Suzuki H, Mori M, Tsukamoto T, Yokomizo A, Naito S, Fujimoto K, Hirao Y, Miyanaga N, Akaza H. Polymorphisms in estrogen related genes may modify the protective effect of isoflavones against prostate cancer risk in Japanese men. European Journal of Cancer Prevention 2010; 19:131-137.

32. Tang L, Yao S, Till C, Goodman PJ, Tangen CM, Wu Y, Kristal AR, Platz EA, Neuhouser ML, Stanczyk FZ. Repeat polymorphisms in estrogen metabolism genes and prostate cancer risk: results from the Prostate Cancer Prevention Trial. Carcinogenesis 2011; 32:1500-1506.

33. Corbin CJ, Grahamlorence S, Mcphaul M, Mason JI, Mendelson CR, Simpson ER. Isolation of a full-length cDNA insert encoding human aromatase system cytochrome P-450 and its expression in nonsteroidogenic cells. Proceedings of the National Academy of Sciences of the United States of America 1988; 85:8948-8952.

34. Carreau S, Hess RA. Oestrogens and spermatogenesis. Philosophical Transactions of the Royal Society B 2010; 365:1517-1535.

35. Munafo MR, Flint J. Meta-analysis of genetic association studies. Trends in Genetics 2004; 20:439-444.

36. Wang H, Li Q, Wang T, Yang G, Wang Y, Zhang X, Sang Q, Wang H, Zhao X, Xing Q. A common polymorphism in the human aromatase gene alters the risk for polycystic ovary syndrome and modifies aromatase activity in vitro. Molecular Human Reproduction 2011; 17:386-391.

37. Pan Z, Fu Z, Song Q, Cao W, Cheng W, Xu X. Genetic polymorphisms and haplotype of hormone-related genes are associated with the risk of breast cancer in Chinese women. Genetics and Molecular Research 2016; 15.

38. Sun M, Du H, Zhu A, Liang H, De Garibay GR, Li F, Li M, Yang X. Genetic Polymorphisms in Estrogen-Related Genes and the Risk of Breast Cancer among Han Chinese Women. International Journal of Molecular Sciences 2015; 16:41214135.

39. Tao M, Cai Q, Zhang Z, Xu W, Kataoka N, Wen W, Xiang Y, Zheng W, Shu X. Polymorphisms in the CYP19A1 (Aromatase) Gene and Endometrial Cancer Risk in Chinese Women. Cancer Epidemiology, Biomarkers \& Prevention 2007; 16:943-949.

40. Hammoud AO, Griffın J, Meikle AW, Gibson M, Peterson CM, Carrell DT. Association of aromatase (TTTAn) repeat polymorphism length and the relationship between obesity and decreased sperm concentration. Human Reproduction 2010; 25:3146-3151. 
41. Olson SH, Bandera EV, Orlow I. Variants in Estrogen Biosynthesis Genes, Sex Steroid Hormone Levels, and Endometrial Cancer: A HuGE Review. American Journal of Epidemiology 2007; 165:235-245.

42. Fernandez R, Esteva I, Gomezgil E, Rumbo T, Almaraz MC, Roda E, Haromora J, Guillamon A, Pasaro E. The (CA)n Polymorphism of ERß Gene is Associated with FtM Transsexualism. The Journal of Sexual Medicine 2014; 11:720-728.

43. Xu P, Zhang X, Xie G, Zhang C, Shen S, Zhang XX, Cao Y, Wang W, Che Y, Xia Y. The (TTTA)n polymorphism in intron 4 of CYP19 and the polycystic ovary syndrome risk in a Chinese population. Molecular Biology Reports 2013; 40:50415047.

44. Luigi G, Laura M, Daniela M, Lucia P, Alberto F, Annalisa T, Carmelo M, Francesca DM, Stefano G, Barbara L. A polymorphic CYP19 TTTA repeat influences aromatase activity and estrogen levels in elderly men: effects on bone metabolism. J Clin Endocrinol Metab 2004; 89:2803-2810.

45. Izabella CO, Wojciech Z, Alina K, Michal M, Jerzy O. Association between gynecomastia and aromatase (CYP19) polymorphisms. European Journal of Endocrinology 2008; 158:721-727.

46. Ahsan H, Whittemore AS, Chen Y, Senie RT, Hamilton SP, Wang Q, Gurvich I, Santella RM. Variants in estrogenbiosynthesis genes CYP17 and CYP19 and breast cancer risk: a family-based genetic association study. Breast Cancer Research Bcr 2004; 7:R71.

47. Miyoshi Y, Iwao K, Ikeda N, Egawa C, Noguchi S. Breast cancer risk associated with polymorphism in CYP19 in Japanese women. International Journal of Cancer 2000; 89:325-328.

48. Elias Z, Joseph L. Synthesis of genetic association studies for pertinent gene-disease associations requires appropriate methodological and statistical approaches. Journal of Clinical Epidemiology 2008; 61:634-645.

\section{Tables}

Table 1 Allele and genotype distribution in the Arg264Cys polymorphism of subjects included in the meta-analysis 


\begin{tabular}{|c|c|c|c|c|c|c|c|}
\hline & \multirow{2}{*}{$\begin{array}{l}\text { Subgroup } \\
\text { (Number of } \\
\text { studies) }\end{array}$} & \multirow[t]{2}{*}{$\begin{array}{l}\text { Sample size } \\
\text { (case/control) }\end{array}$} & \multicolumn{2}{|c|}{$\begin{array}{l}\text { Allele frequency } \\
\text { (case/control) }\end{array}$} & \multicolumn{3}{|c|}{$\begin{array}{l}\text { Genotype frequency } \\
\text { (case/control) }\end{array}$} \\
\hline & & & C & $\mathrm{T}$ & $\mathrm{CC}$ & $\mathrm{CT}$ & $\mathrm{TT}$ \\
\hline Overall & & $11824 / 11368$ & $22162 / 21260$ & $1486 / 1476$ & $10453 / 10021$ & $1256 / 1218$ & $115 / 129$ \\
\hline \multirow[t]{5}{*}{ Ethnicity } & $\begin{array}{l}\text { Caucasian } \\
\text { (4) }\end{array}$ & $2466 / 2588$ & $4753 / 5001$ & $179 / 175$ & $2290 / 2415$ & $173 / 171$ & $3 / 2$ \\
\hline & Asian (2) & 208/301 & $301 / 464$ & $115 / 138$ & $113 / 185$ & $75 / 94$ & $20 / 22$ \\
\hline & Indian (1) & $100 / 100$ & $155 / 166$ & $45 / 34$ & $59 / 73$ & $37 / 20$ & $4 / 7$ \\
\hline & $\begin{array}{l}\text { African- } \\
\text { American } \\
\text { (1) }\end{array}$ & $131 / 341$ & $219 / 565$ & $43 / 117$ & $91 / 236$ & $37 / 93$ & $3 / 12$ \\
\hline & $\begin{array}{l}\text { Mixed } \\
\text { population } \\
(1)\end{array}$ & $8919 / 8038$ & $16734 / 15064$ & $1104 / 1012$ & 7900/7112 & $934 / 840$ & $85 / 86$ \\
\hline \multirow{3}{*}{$\begin{array}{l}\text { Source of } \\
\text { control }\end{array}$} & PB (4) & $10410 / 9867$ & $19564 / 18493$ & $1246 / 1241$ & $9255 / 8725$ & $1064 / 1043$ & $91 / 99$ \\
\hline & HB (4) & $208 / 301$ & $301 / 464$ & $115 / 138$ & $113 / 185$ & $75 / 94$ & $20 / 22$ \\
\hline & $\mathrm{PB}+\mathrm{HB}(1)$ & $865 / 839$ & $1668 / 1635$ & $62 / 43$ & $803 / 796$ & $62 / 43$ & $0 / 0$ \\
\hline \multirow[t]{7}{*}{$\begin{array}{l}\text { Genotyping } \\
\text { method }\end{array}$} & $\begin{array}{l}\text { PCR-RFLP } \\
\text { (3) }\end{array}$ & $295 / 528$ & $491 / 926$ & $99 / 130$ & $206 / 417$ & $79 / 92$ & $10 / 19$ \\
\hline & $\begin{array}{l}\text { Taqman } \\
\text { (2) }\end{array}$ & $9784 / 8877$ & $18402 / 16699$ & $1166 / 1055$ & $8703 / 7908$ & $996 / 883$ & $85 / 86$ \\
\hline & $\begin{array}{l}\text { PCR-SSCP } \\
\text { (1) }\end{array}$ & $101 / 114$ & $132 / 171$ & $70 / 57$ & $45 / 67$ & $42 / 37$ & $14 / 10$ \\
\hline & PCR-RFLP & $241 / 261$ & $464 / 502$ & $18 / 20$ & $223 / 242$ & $18 / 18$ & $0 / 1$ \\
\hline & $\begin{array}{l}\text { \&PCR- } \\
\text { SSCP (1) }\end{array}$ & & & & & & \\
\hline & $\begin{array}{l}\text { High- } \\
\text { throughput } \\
\text { genotyping } \\
(1)\end{array}$ & $131 / 341$ & $219 / 565$ & $43 / 117$ & $91 / 236$ & $37 / 93$ & $3 / 12$ \\
\hline & $\begin{array}{l}\text { SNPlexTM } \\
\text { Genotyping } \\
\text { System (1) }\end{array}$ & $1272 / 1247$ & $2454 / 2397$ & $90 / 97$ & $1185 / 1151$ & $84 / 95$ & $3 / 1$ \\
\hline \multirow[t]{2}{*}{$\begin{array}{l}\text { Sample } \\
\text { acquisition }\end{array}$} & $\begin{array}{l}\text { Peripheral } \\
\text { blood (7) }\end{array}$ & $11617 / 11081$ & $21838 / 20801$ & $1396 / 1361$ & $10326 / 9830$ & $1186 / 1141$ & $105 / 110$ \\
\hline & $\begin{array}{l}\text { Peripheral } \\
\text { blood or } \\
\text { frozen } \\
\text { prostate } \\
\text { tissue (2) }\end{array}$ & $207 / 287$ & $324 / 459$ & $90 / 115$ & $127 / 119$ & 70/77 & $10 / 19$ \\
\hline
\end{tabular}


$P B$ population-based, $H B$ hospital-based, $P C R$ polymerase chain reaction, $R F L P$ restriction fragment length polymorphism, SSCP single-strand conformation polymorphism.

Table 2 Meta-analysis of the association between the Arg264Cys polymorphism and prostate cancer 


\begin{tabular}{|c|c|c|c|c|c|c|c|c|c|}
\hline \multirow[t]{2}{*}{$\begin{array}{l}\text { Genetic } \\
\text { model }\end{array}$} & \multirow[t]{2}{*}{ Subgroup } & & \multirow[t]{2}{*}{$\begin{array}{l}\text { Number of } \\
\text { studies }\end{array}$} & \multicolumn{3}{|c|}{ Test of association } & \multirow[t]{2}{*}{$P(\%)$} & \multicolumn{2}{|c|}{$\begin{array}{l}\text { Publication } \\
\text { bias }(P)\end{array}$} \\
\hline & & & & OR & $95 \% \mathrm{Cl}$ & $P$ & & Begg & Egger \\
\hline \multirow[t]{9}{*}{ T vs. C } & Ethnicity & Overall & 9 & 1.08 & $\begin{array}{l}0.94- \\
1.24\end{array}$ & 0.27 & 30.9 & 0.08 & 0.10 \\
\hline & & Caucasian & 4 & 1.12 & $\begin{array}{l}0.84- \\
1.48\end{array}$ & 0.44 & 30.3 & & \\
\hline & & Asian & 2 & 1.24 & $\begin{array}{l}0.76- \\
2.02\end{array}$ & 0.40 & 64.6 & & \\
\hline & $\begin{array}{l}\text { Source of } \\
\text { control }\end{array}$ & PB & 4 & 0.98 & $\begin{array}{l}0.90- \\
1.06\end{array}$ & 0.62 & 0.0 & & \\
\hline & & $\mathrm{HB}$ & 4 & 1.23 & $\begin{array}{l}0.95 \\
1.60\end{array}$ & 0.12 & 17.5 & & \\
\hline & $\begin{array}{l}\text { Genotyping } \\
\text { method }\end{array}$ & PCR-RFLP & 3 & 1.19 & $\begin{array}{l}0.87- \\
1.62\end{array}$ & 0.27 & 6.1 & & \\
\hline & & Taqman & 2 & 1.12 & $\begin{array}{l}0.79- \\
1.57\end{array}$ & 0.52 & 67.8 & & \\
\hline & $\begin{array}{l}\text { Sample } \\
\text { acquisition }\end{array}$ & Peripheral blood & 7 & 1.01 & $\begin{array}{l}0.94- \\
1.09\end{array}$ & 0.79 & 38.5 & & \\
\hline & & $\begin{array}{l}\text { Peripheral blood or } \\
\text { frozen prostate tissue }\end{array}$ & 2 & 1.13 & $\begin{array}{l}0.82- \\
1.54\end{array}$ & 0.46 & 27.7 & & \\
\hline \multirow[t]{9}{*}{$\begin{array}{l}\mathrm{CT}+\mathrm{TT} \\
\text { vs. CC }\end{array}$} & Ethnicity & Overall & 9 & 1.13 & $\begin{array}{l}0.95- \\
1.34\end{array}$ & 0.17 & 40.6 & 0.08 & 0.08 \\
\hline & & Caucasian & 4 & 1.13 & $\begin{array}{l}0.83- \\
1.54\end{array}$ & 0.44 & 37.1 & & \\
\hline & & Asian & 2 & 1.31 & $\begin{array}{l}0.73- \\
2.33\end{array}$ & 0.37 & 60.2 & & \\
\hline & $\begin{array}{l}\text { Source of } \\
\text { control }\end{array}$ & PB & 4 & 0.99 & $\begin{array}{l}0.90- \\
1.08\end{array}$ & 0.75 & 0.0 & & \\
\hline & & $\mathrm{HB}$ & 4 & 1.35 & $\begin{array}{l}1.02- \\
1.78\end{array}$ & 0.04 & 32.0 & & \\
\hline & $\begin{array}{l}\text { Genotype } \\
\text { method }\end{array}$ & PCR-RFLP & 3 & 1.39 & $\begin{array}{l}0.89- \\
2.17\end{array}$ & 0.15 & 35.3 & & \\
\hline & & Taqman & 2 & 1.13 & $\begin{array}{l}0.80- \\
1.59\end{array}$ & 0.49 & 67.1 & & \\
\hline & $\begin{array}{l}\text { Sample } \\
\text { acquisition }\end{array}$ & Peripheral blood & 7 & 1.09 & $\begin{array}{l}0.92- \\
1.29\end{array}$ & 0.33 & 36.3 & & \\
\hline & & $\begin{array}{l}\text { Peripheral blood or } \\
\text { frozen prostate tissue }\end{array}$ & 2 & 1.33 & $\begin{array}{l}0.70- \\
2.51\end{array}$ & 0.38 & 63.2 & & \\
\hline \multirow[t]{3}{*}{$\begin{array}{l}\text { TT vs. } \\
\text { CT+CC }\end{array}$} & Ethnicity & Overall & 9 & 0.94 & $\begin{array}{l}0.73- \\
1.21\end{array}$ & 0.61 & 0.0 & 0.35 & 0.41 \\
\hline & & Caucasian & 4 & 1.83 & $\begin{array}{l}0.51- \\
6.62\end{array}$ & 0.35 & 0.0 & & \\
\hline & & Asian & 2 & 1.27 & $\begin{array}{l}0.67- \\
2.41\end{array}$ & 0.47 & 0.0 & & \\
\hline
\end{tabular}




\begin{tabular}{|c|c|c|c|c|c|c|c|c|c|}
\hline & $\begin{array}{l}\text { Source of } \\
\text { control }\end{array}$ & $\mathrm{PB}$ & 4 & 0.91 & $\begin{array}{l}0.68- \\
1.21\end{array}$ & 0.49 & 0.0 & & \\
\hline & & $\mathrm{HB}$ & 4 & 1.06 & $\begin{array}{l}0.61- \\
1.85\end{array}$ & 0.84 & 0.0 & & \\
\hline & $\begin{array}{l}\text { Genotype } \\
\text { method }\end{array}$ & PCR-RFLP & 3 & 0.80 & $\begin{array}{l}0.37- \\
1.69\end{array}$ & 0.55 & 0.0 & & \\
\hline & & Taqman & 2 & 0.89 & $\begin{array}{l}0.66- \\
1.20\end{array}$ & 0.45 & 0.0 & & \\
\hline & $\begin{array}{l}\text { Sample } \\
\text { acquisition }\end{array}$ & Peripheral blood & 7 & 0.96 & $\begin{array}{l}0.74- \\
1.26\end{array}$ & 0.79 & 0.0 & & \\
\hline & & $\begin{array}{l}\text { Peripheral blood or } \\
\text { frozen prostate tissue }\end{array}$ & 2 & 0.73 & $\begin{array}{l}0.33- \\
1.60\end{array}$ & 0.43 & 0.0 & & \\
\hline $\begin{array}{l}\text { TT vs. } \\
\text { CC }\end{array}$ & Ethnicity & Overall & 9 & 0.96 & $\begin{array}{l}0.74- \\
1.24\end{array}$ & 0.76 & 0.0 & 0.35 & 0.31 \\
\hline & & Caucasian & 4 & 1.85 & $\begin{array}{l}0.51- \\
6.69\end{array}$ & 0.35 & 0.0 & & \\
\hline & & Asian & 2 & 1.42 & $\begin{array}{l}0.74- \\
2.74\end{array}$ & 0.30 & 37.3 & & \\
\hline & $\begin{array}{l}\text { Source of } \\
\text { control }\end{array}$ & PB & 4 & 0.91 & $\begin{array}{l}0.68- \\
1.21\end{array}$ & 0.50 & 0.0 & & \\
\hline & & $\mathrm{HB}$ & 4 & 1.21 & $\begin{array}{l}0.69- \\
2.14\end{array}$ & 0.51 & 0.0 & & \\
\hline & $\begin{array}{l}\text { Genotype } \\
\text { method }\end{array}$ & PCR-RFLP & 3 & 0.88 & $\begin{array}{l}0.41- \\
1.88\end{array}$ & 0.73 & 0.0 & & \\
\hline & & Taqman & 2 & 0.89 & $\begin{array}{l}0.66- \\
1.20\end{array}$ & 0.45 & 0.0 & & \\
\hline & $\begin{array}{l}\text { Sample } \\
\text { acquisition }\end{array}$ & Peripheral blood & 7 & 0.98 & $\begin{array}{l}0.75- \\
1.29\end{array}$ & 0.89 & 0.0 & & \\
\hline & & $\begin{array}{l}\text { Peripheral blood or } \\
\text { frozen prostate tissue }\end{array}$ & 2 & 0.80 & $\begin{array}{l}0.36- \\
1.78\end{array}$ & 0.59 & 0.0 & & \\
\hline CT vs.CC & Ethnicity & Overall & 9 & 1.04 & $\begin{array}{l}0.96- \\
1.13\end{array}$ & 0.37 & 44.0 & 0.08 & 0.08 \\
\hline & & Caucasian & 4 & 1.07 & $\begin{array}{l}0.86- \\
1.34\end{array}$ & 0.53 & 41.7 & & \\
\hline & & Asian & 2 & 1.27 & $\begin{array}{l}0.86- \\
1.86\end{array}$ & 0.23 & 41.2 & & \\
\hline & $\begin{array}{l}\text { Source of } \\
\text { control }\end{array}$ & PB & 4 & 0.99 & $\begin{array}{l}0.91- \\
1.09\end{array}$ & 0.90 & 0.0 & & \\
\hline & & $\mathrm{HB}$ & 4 & 1.40 & $\begin{array}{l}1.04- \\
1.88\end{array}$ & 0.03 & 36.7 & & \\
\hline & $\begin{array}{l}\text { Genotype } \\
\text { method }\end{array}$ & PCR-RFLP & 3 & 1.52 & $\begin{array}{l}0.89- \\
2.60\end{array}$ & 0.13 & 49.7 & & \\
\hline & & Taqman & 2 & 1.13 & $\begin{array}{l}0.81- \\
1.58\end{array}$ & 0.47 & 65.0 & & \\
\hline & $\begin{array}{l}\text { Sample } \\
\text { acquisition }\end{array}$ & Peripheral blood & 7 & 1.08 & $\begin{array}{l}0.92- \\
1.27\end{array}$ & 0.35 & 28.5 & & \\
\hline
\end{tabular}


$P B$ population-based, $H B$ hospital-based, $P C R$ polymerase chain reaction, $R F L P$ restriction fragment length polymorphism. We couldn'd perform subgroup analyses for subgroups with only one study.

Table 3 Meta-analysis of the association between the (TTTA)n repeat polymorphism and prostate cancer 


\begin{tabular}{|c|c|c|c|c|c|c|c|c|c|}
\hline \multirow[t]{2}{*}{$\begin{array}{l}\text { Repeat } \\
\text { number }\end{array}$} & \multirow[t]{2}{*}{ Subgroup } & & \multicolumn{2}{|c|}{$\begin{array}{l}\text { Number of } \\
\text { studies }\end{array}$} & \multicolumn{2}{|c|}{ Test of association } & \multirow[t]{2}{*}{$R(\%)$} & \multicolumn{2}{|c|}{$\begin{array}{l}\text { Publication } \\
\text { bias }(P)\end{array}$} \\
\hline & & & & OR & $95 \% \mathrm{Cl}$ & $P$ & & Begg & Egger \\
\hline \multirow[t]{6}{*}{7} & Ethnicity & Overall & 6 & 0.95 & $\begin{array}{l}0.86- \\
1.05\end{array}$ & 0.34 & 17.8 & 0.06 & 0.02 \\
\hline & & Asian & 3 & 0.96 & $\begin{array}{l}0.80- \\
1.15\end{array}$ & 0.66 & 46.6 & & \\
\hline & $\begin{array}{l}\text { Source of } \\
\text { control }\end{array}$ & PB & 2 & 0.91 & $\begin{array}{l}0.79- \\
1.05\end{array}$ & 0.21 & 16.7 & & \\
\hline & & $\mathrm{HB}$ & 3 & 0.96 & $\begin{array}{l}0.80- \\
1.15\end{array}$ & 0.66 & 46.6 & & \\
\hline & $\begin{array}{l}\text { Genotype } \\
\text { method }\end{array}$ & PCR-RFLP & 2 & 0.93 & $\begin{array}{l}0.62- \\
1.40\end{array}$ & 0.73 & 63.2 & & \\
\hline & & $\begin{array}{l}\text { Capillary } \\
\text { electrophoresis }\end{array}$ & 2 & 0.97 & $\begin{array}{l}0.85- \\
1.11\end{array}$ & 0.65 & 0.0 & & \\
\hline \multirow[t]{6}{*}{8} & Ethnicity & Overall & 6 & 1.34 & $\begin{array}{l}1.14- \\
1.58\end{array}$ & 0.001 & 0.0 & 0.06 & 0.02 \\
\hline & & Asian & 3 & 1.27 & $\begin{array}{l}0.88- \\
1.85\end{array}$ & 0.17 & 26.2 & & \\
\hline & $\begin{array}{l}\text { Source of } \\
\text { control }\end{array}$ & PB & 2 & 1.41 & $\begin{array}{l}1.13- \\
1.74\end{array}$ & 0.002 & 0.0 & & \\
\hline & & $\mathrm{HB}$ & 3 & 1.27 & $\begin{array}{l}0.88- \\
1.85\end{array}$ & 0.21 & 26.2 & & \\
\hline & $\begin{array}{l}\text { Genotype } \\
\text { method }\end{array}$ & PCR-RFLP & 2 & 1.36 & $\begin{array}{l}0.93- \\
1.98\end{array}$ & 0.12 & 0.0 & & \\
\hline & & $\begin{array}{l}\text { Capillary } \\
\text { electrophoresis }\end{array}$ & 2 & 1.34 & $\begin{array}{l}1.09- \\
1.65\end{array}$ & 0.006 & 0.0 & & \\
\hline \multirow[t]{4}{*}{10} & Ethnicity & Overall & 5 & 1.49 & $\begin{array}{l}0.94- \\
2.36\end{array}$ & 0.09 & 11.0 & 0.81 & 0.48 \\
\hline & & Asian & 3 & 1.35 & $\begin{array}{l}0.66- \\
2.83\end{array}$ & 0.41 & 39.3 & & \\
\hline & $\begin{array}{l}\text { Source of } \\
\text { control }\end{array}$ & $\mathrm{HB}$ & 3 & 1.36 & $\begin{array}{l}0.66- \\
2.83\end{array}$ & 0.41 & 39.3 & & \\
\hline & $\begin{array}{l}\text { Genotype } \\
\text { method }\end{array}$ & $\begin{array}{l}\text { Capillary } \\
\text { electrophoresis }\end{array}$ & 2 & 1.58 & $\begin{array}{l}0.88- \\
2.85\end{array}$ & 0.13 & 12.4 & & \\
\hline \multirow[t]{4}{*}{11} & & Overall & 5 & 0.95 & $\begin{array}{l}0.84- \\
1.08\end{array}$ & 0.43 & 9.9 & 0.46 & 0.50 \\
\hline & & Asian & 3 & 1.02 & $\begin{array}{l}0.84- \\
1.24\end{array}$ & 0.83 & 0.0 & & \\
\hline & $\begin{array}{l}\text { Source of } \\
\text { control }\end{array}$ & $\mathrm{HB}$ & 3 & 1.02 & $\begin{array}{l}0.84- \\
1.24\end{array}$ & 0.83 & 0.0 & & \\
\hline & $\begin{array}{l}\text { Genotype } \\
\text { method }\end{array}$ & $\begin{array}{l}\text { Capillary } \\
\text { electrophoresis }\end{array}$ & 2 & 0.74 & $\begin{array}{l}0.38- \\
1.45\end{array}$ & 0.38 & 60.2 & & \\
\hline 12 & Ethnicity & Overall & 6 & 0.85 & $\begin{array}{l}0.64- \\
1.12\end{array}$ & 0.24 & 52.8 & 1.00 & 0.81 \\
\hline
\end{tabular}




\begin{tabular}{|c|c|c|c|c|c|c|c|c|c|}
\hline & & Asian & 3 & 0.92 & $\begin{array}{l}0.43- \\
1.96\end{array}$ & 0.83 & 79.7 & & \\
\hline & $\begin{array}{l}\text { Source of } \\
\text { control }\end{array}$ & PB & 2 & 0.78 & $\begin{array}{l}0.56- \\
1.10\end{array}$ & 0.16 & 0.0 & & \\
\hline & & $\mathrm{HB}$ & 3 & 0.92 & $\begin{array}{l}0.43- \\
1.96\end{array}$ & 0.83 & 79.7 & & \\
\hline & $\begin{array}{l}\text { Genotype } \\
\text { method }\end{array}$ & PCR-RFLP & 2 & 0.64 & $\begin{array}{l}0.46- \\
0.90\end{array}$ & 0.01 & 0.0 & & \\
\hline & & $\begin{array}{l}\text { Capillary } \\
\text { electrophoresis }\end{array}$ & 2 & 0.87 & $\begin{array}{l}0.69- \\
1.11\end{array}$ & 0.27 & 0.0 & & \\
\hline \multirow[t]{3}{*}{13} & Ethnicity & Overall & 4 & 1.07 & $\begin{array}{l}0.64- \\
1.77\end{array}$ & 0.80 & 0.0 & 0.31 & 0.001 \\
\hline & & Asian & 3 & 0.95 & $\begin{array}{l}0.45- \\
2.02\end{array}$ & 0.90 & 0.0 & & \\
\hline & $\begin{array}{l}\text { Source of } \\
\text { control }\end{array}$ & $\mathrm{HB}$ & 3 & 0.95 & $\begin{array}{l}0.45- \\
2.02\end{array}$ & 0.90 & 0.0 & & \\
\hline
\end{tabular}

$P B$ population-based, $H B$ hospital-based, $P C R$ polymerase chain reaction, $R F L P$ restriction fragment length polymorphism. We couldn'd perform subgroup analyses for subgroups with only one study.

\section{Figures}




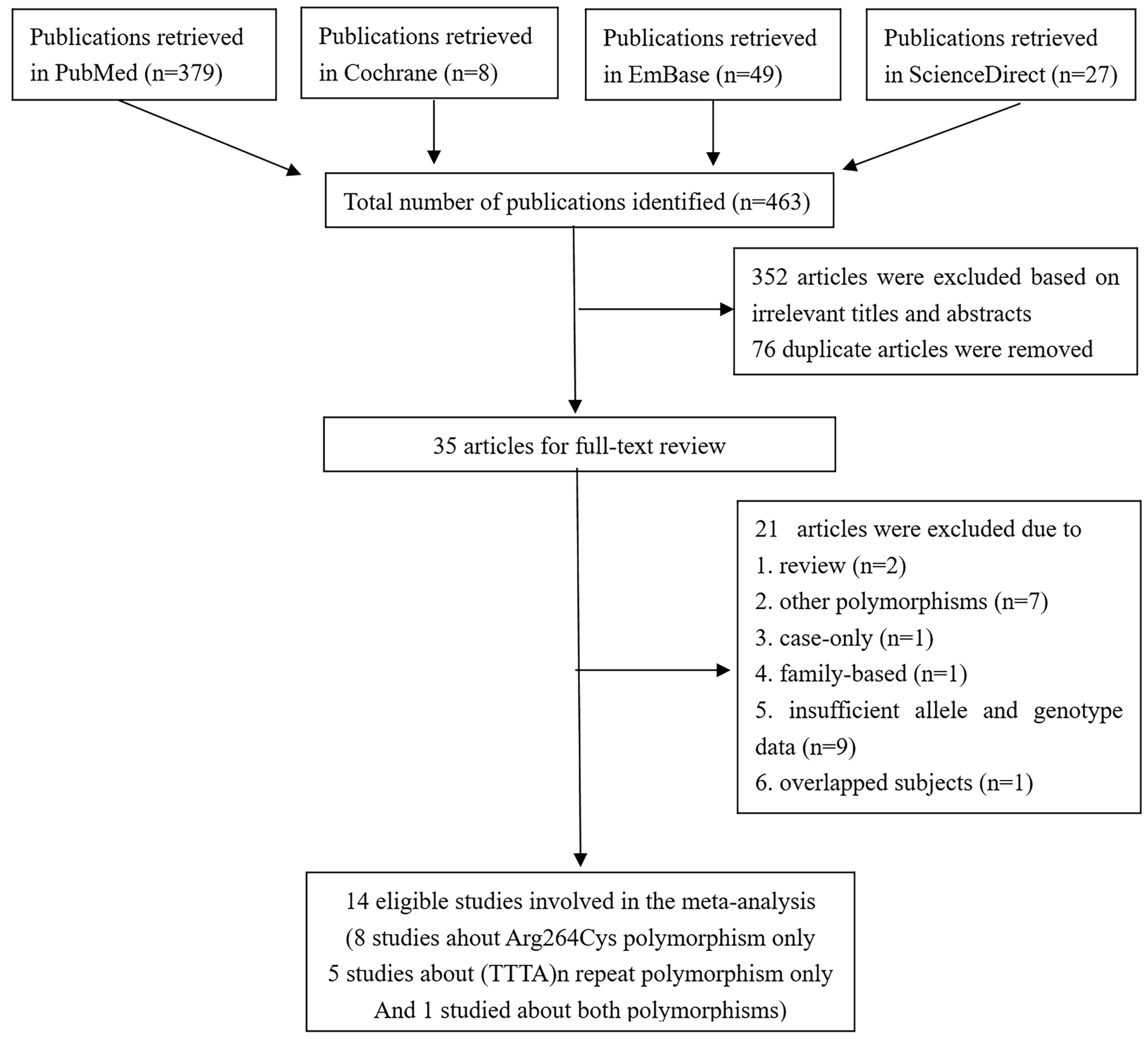

Figure 1

Selection of studies for meta-analysis. 


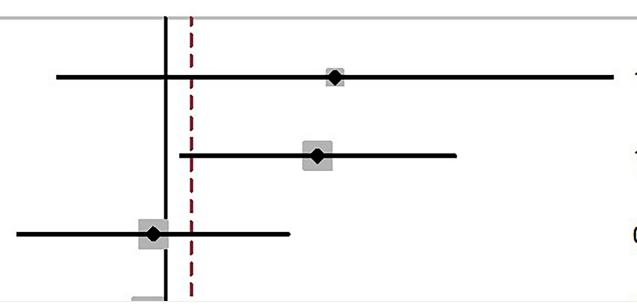

$1.68(0.72,3.91)$

\section{Figure 2}

Forest plot for the association between the Arg264Cys polymorphism and prostate cancer (T vs. C). 


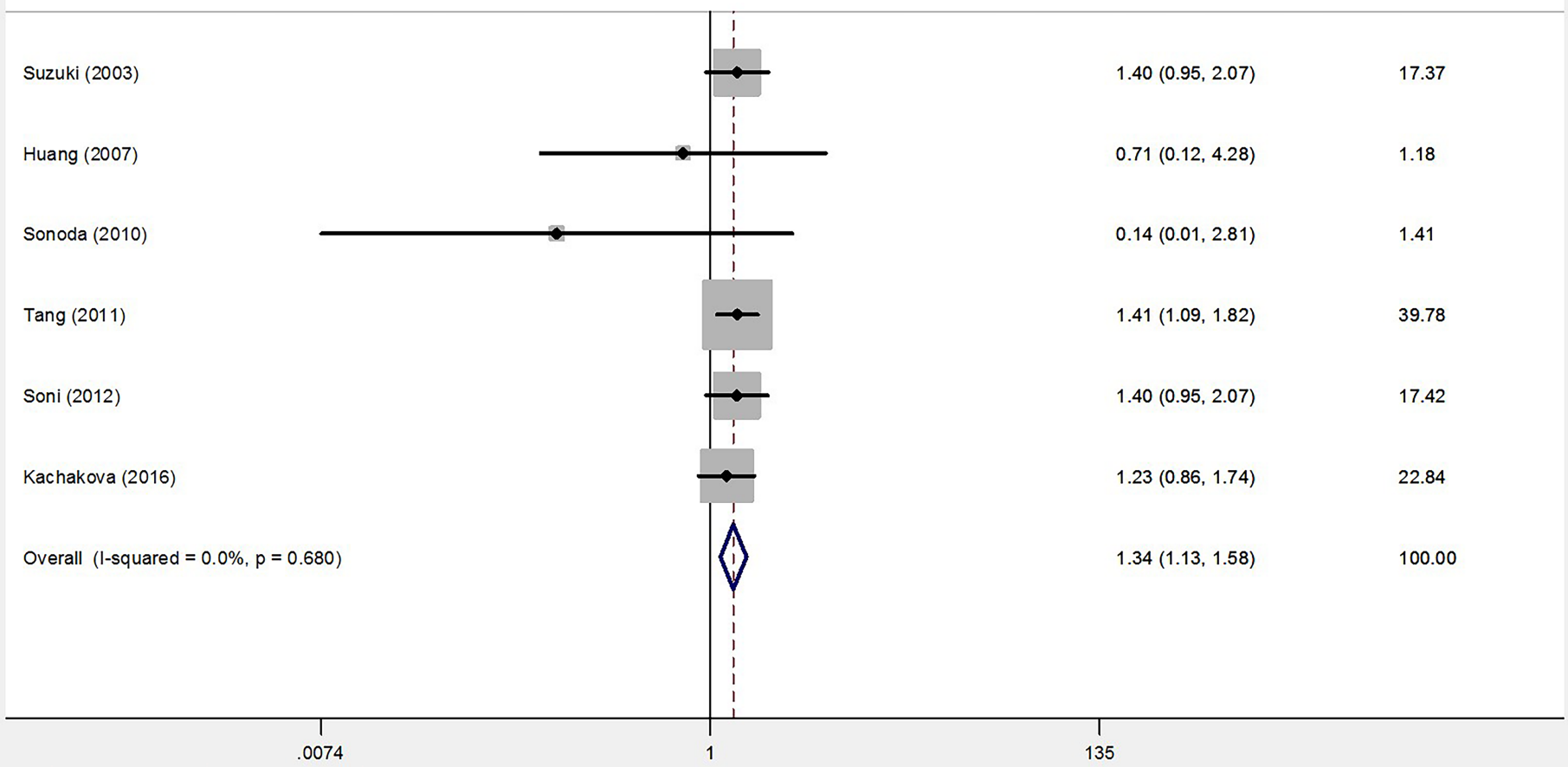

\section{Figure 3}

Forest plot for the association between the 8-repeat allele and prostate cancer. 
Meta-analysis estimates, given named study is omitted

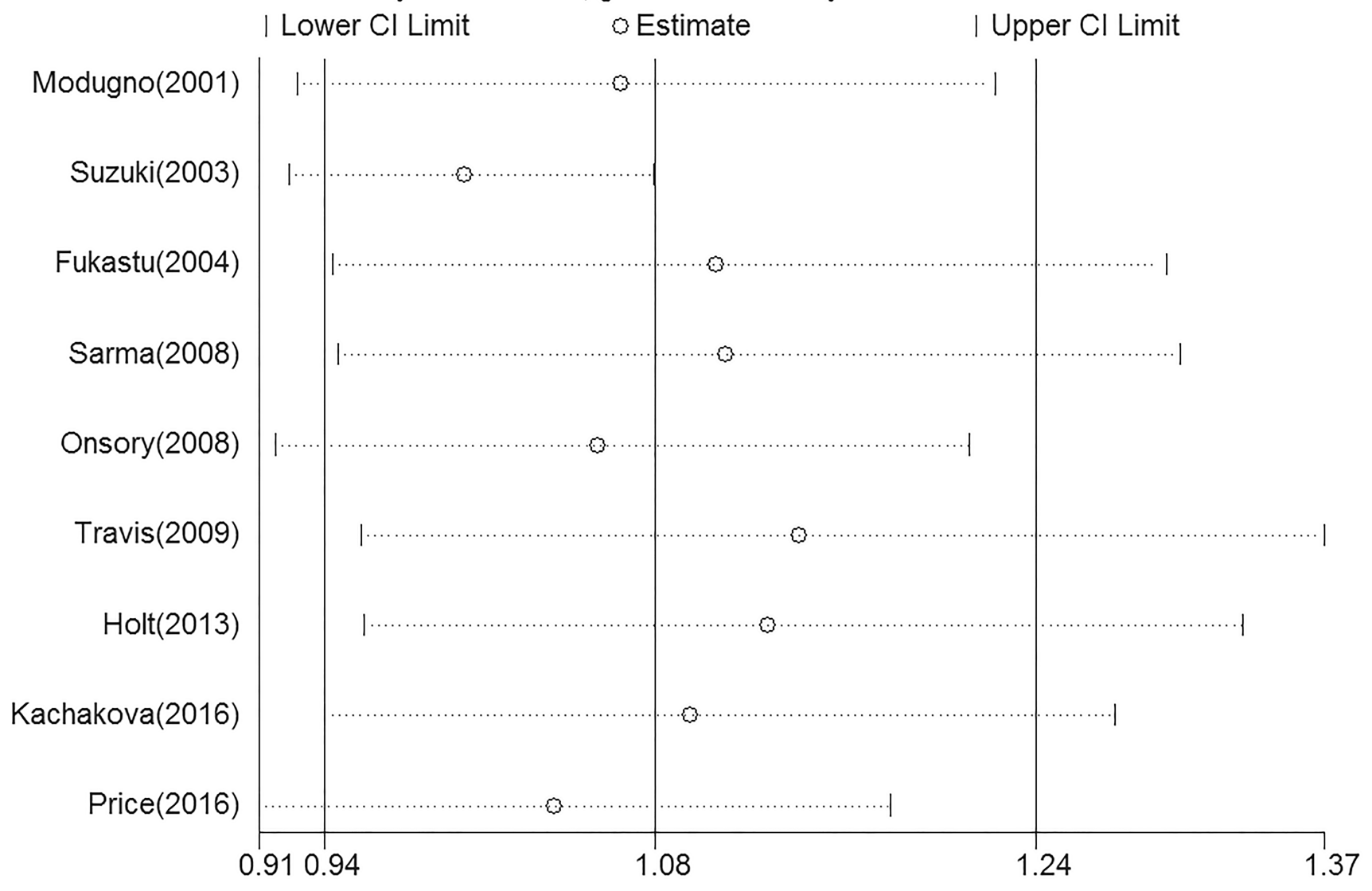

\section{Figure 4}

Sensitivity analysis of studies on the Arg264Cys polymorphism and prostate cancer (T vs. C). 


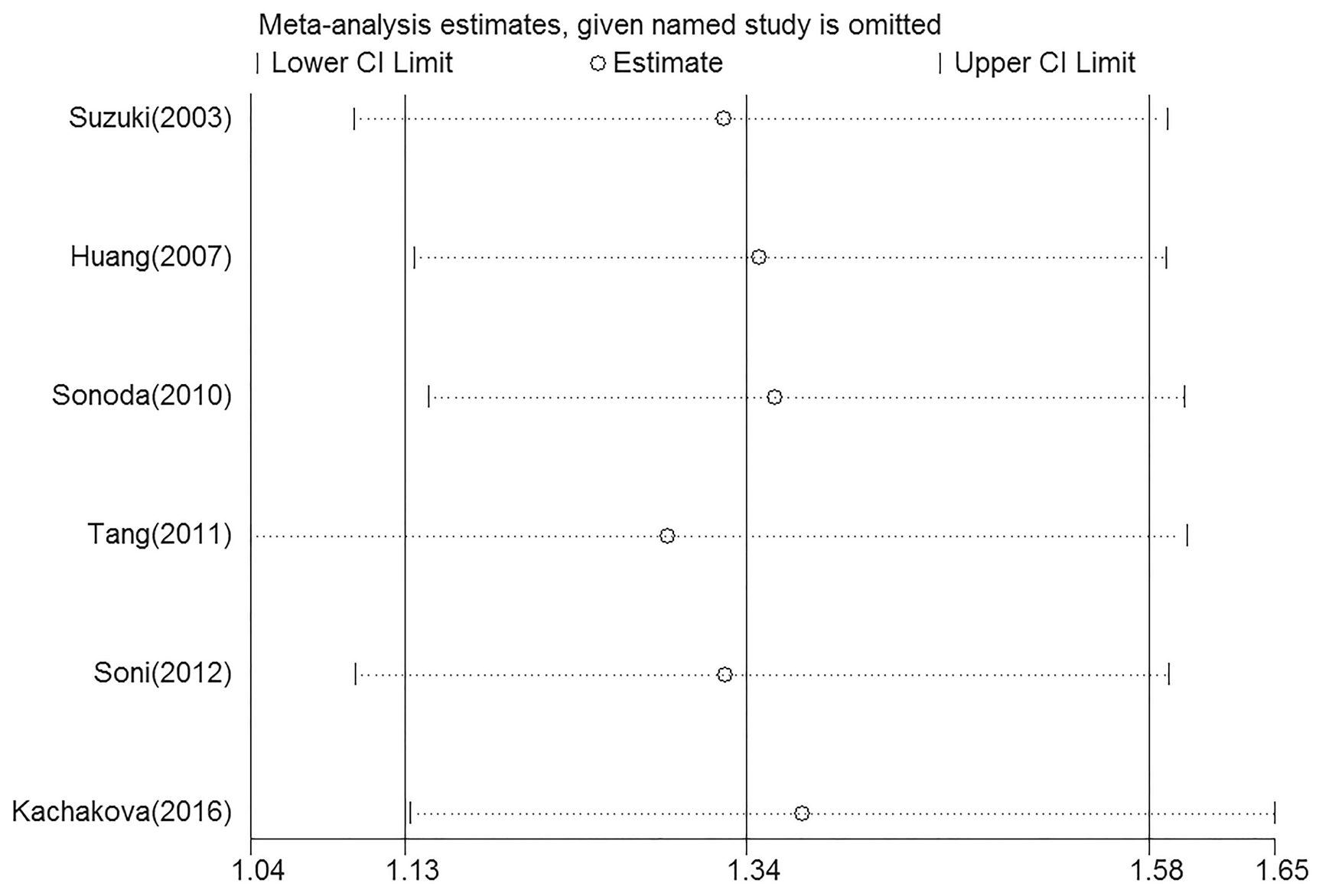

Figure 5

Sensitivity analysis of studies on the 8-repeat allele and prostate cancer. 


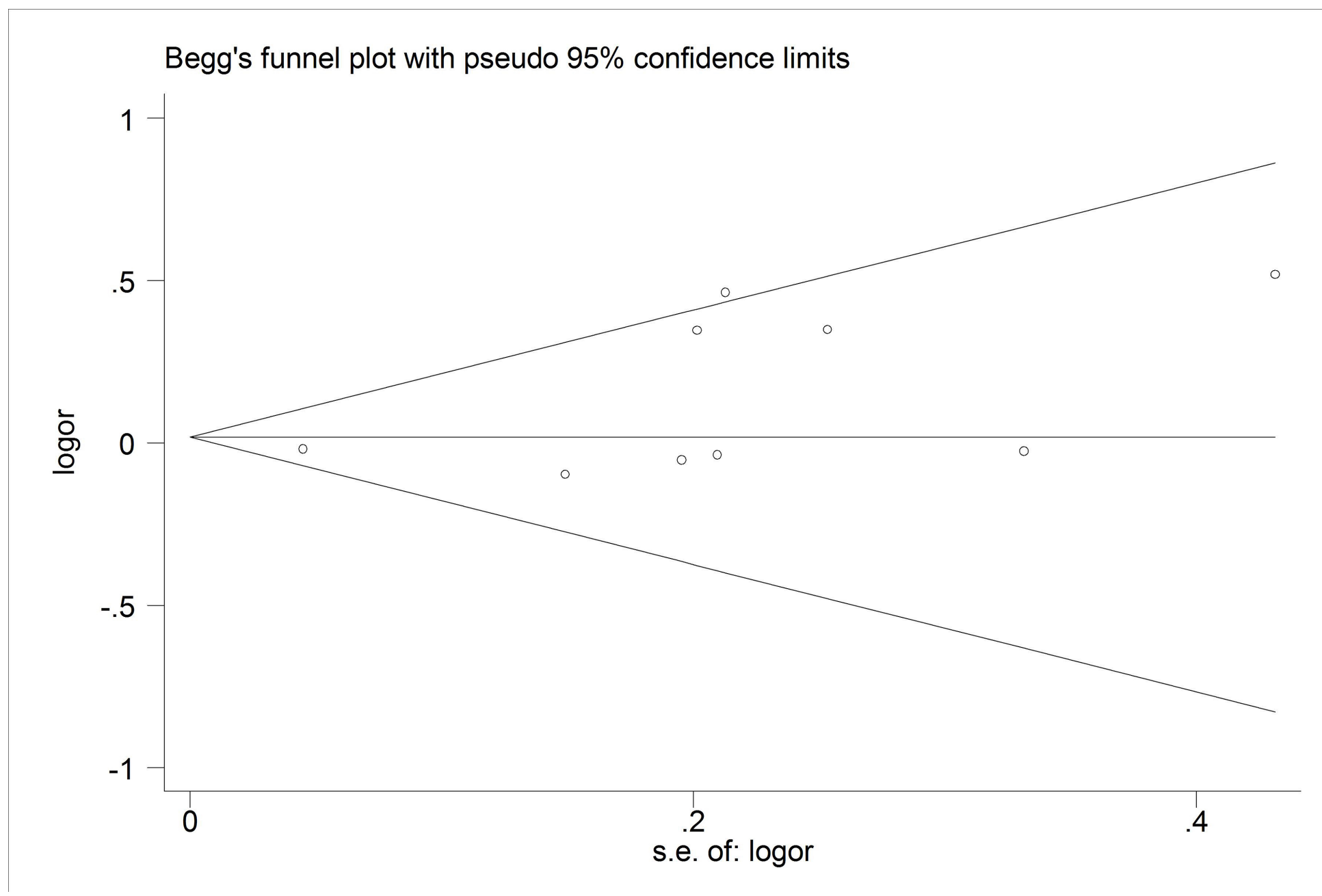

Figure 6

Begg's funnel plot for studies addressing the Arg264Cys polymorphism in prostate cancer (T vs. C).

\section{Supplementary Files}

This is a list of supplementary files associated with this preprint. Click to download.

- searchstrategyuploaded.docx

- Prismachecklistuploaded.doc

- Additionalfile1 revised.docx

- Additionalfile2revised.doc 